F. Reprod. Fert. (1967) 13, 23-30

\title{
THE TESTIS OF THE AFRICAN ELEPHANT (LOXODONTA AFRICANA)
}

\author{
II. DEVELOPMENT, PUBERTY AND WEIGHT
}

\author{
OSCAR W. JOHNSON AND IRVEN O. BUSS \\ Department of Biology, Moorhead State College, Moorhead, Minnesota, and \\ Department of Zoology, Washington State University, Pullman, Washington
}

(Received 9th December 1965)

Summary. Relatively slow testicular growth characterizes the first 6 years of life. Following this period, gonad development is rapid and by 9 to 11 years of age the testicular components reach adult percentages.

A division of the seminiferous epithelium into spermatogonia and Sertoli cells was found in a 1-year-old specimen. The interstitium, however, appears to remain undifferentiated until 2 years of age.

Curves depicting the history of each testicular cell type are shown. Cellular abundance stabilizes at adult levels by the time the testis reaches a weight of $700 \mathrm{~g}$.

The pubertal period seems to involve approximately 4 years. The start of puberty is individually variable over an apparent range of 3 to 14 years of age. This broad pubertal span appears to be involved in variations of testis weights and testis- to body-weight ratios within the collection series.

The heaviest testis encountered in this study weighed approximately $2 \mathrm{~kg}$. Based upon an earlier report, maximum testis weight in the African elephant probably approximates $4 \mathrm{~kg}$. Comparative testis- to body-weight ratios for a variety of mammals indicate that elephant testes are small in relative terms.

\section{INTRODUCTION AND METHODS}

An introduction to the content of this paper, with a discussion of methods, was presented earlier (Johnson \& Buss, 1967).

\section{RESULTS AND DISCUSSION \\ THE PATTERN OF DEVELOPMENT}

Table 1 presents a summary of testicular data grouped according to relative age. Various aspects of these data will be used throughout this paper.

During the first year of life, the testes are relatively large in proportion to body weight (specimen 60). In comparison to the first year value, testis weights appear to double by $4 \frac{1}{2}$ to 6 years of age (specimens 55 and 94). This size 
increase is, however, much less than general body growth over the same period and, as the Table indicates, the testis- to body-weight ratios decline steadily until about the 6th year of life. At this time, the testes begin to grow more rapidly (specimens 98 and 34). Gonad weight at the onset of rapid development (around $30 \mathrm{~g}$ ) increases by at least ten times over the ensuing 2 to 3 years (specimens 95, 61 and 64). The testes of some individuals appear to grow even more rapidly. For example, the gonads of specimens 87 and 1 weighed
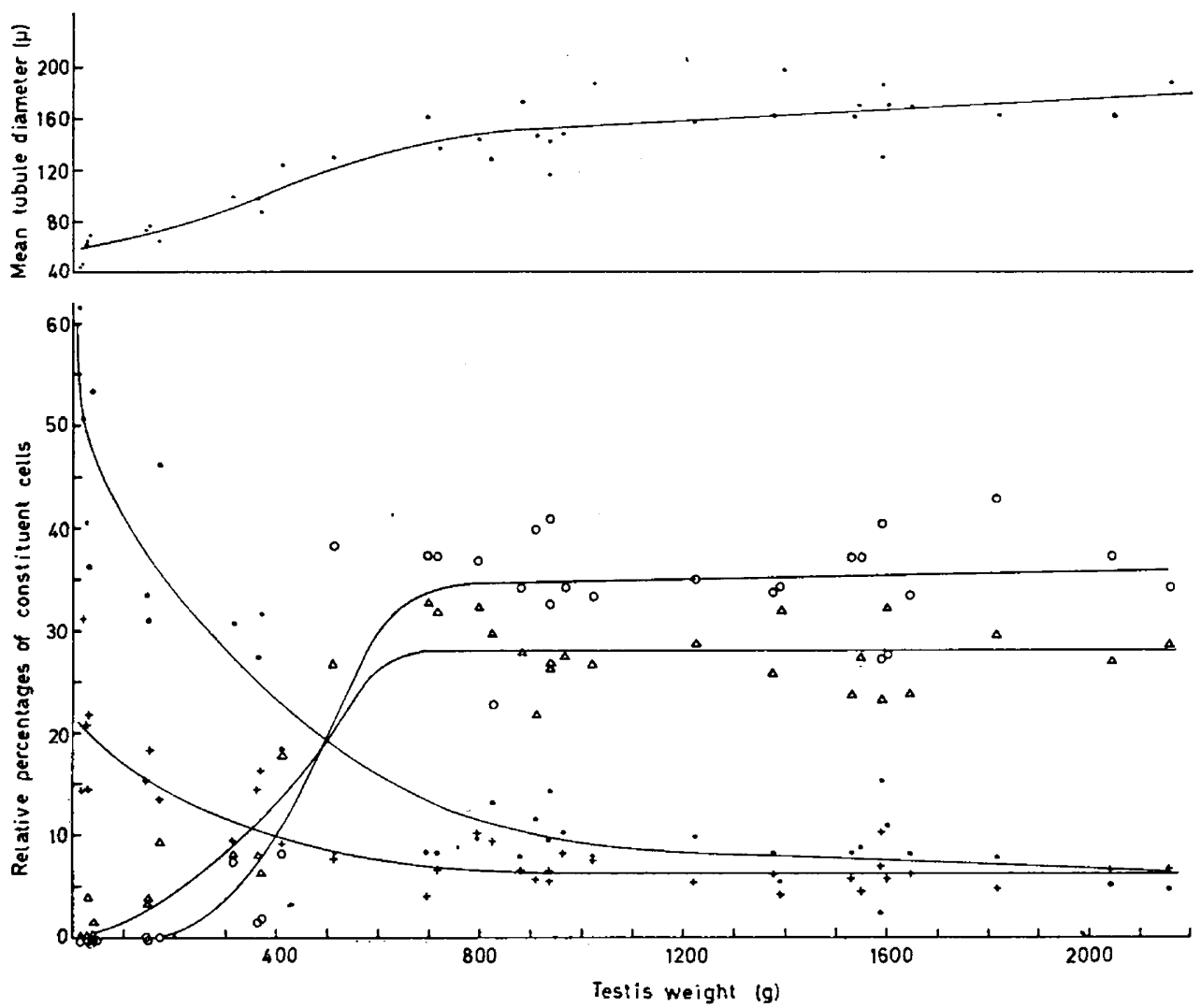

TEXT-FIG. 1. The developmental history of the cells of the seminiferous epithelium, and the correlative diameter status of the tubules. - Sertoli cells; + , spermatogonia; $O$, spermatid-spermatozoa; $\Delta$, spermatocytes.

936 and $1589 \mathrm{~g}$, respectively. These weights represent increases of the order of 30 and 50 times the probable weight at 5 to 6 years of age.

During the rapid development phase, the seminiferous epithelium produces the first spermatids and spermatozoa. The initial sparse occurrence of these elements was found at a testicular weight of around $300 \mathrm{~g}$, which corresponds to an approximate age of 7 to 8 years. Upon reaching the latter developmental level, the attainment of histologically mature tissue appears to take place rapidly. By 9 to 11 years, the relative percentages of testicular components are similar to those of older animals. In general then, testicular development is delayed until approximately 6 years of age, whereupon relatively rapid develop- 
ment over the next 4 to 5 years brings the organs to a histological level comparable to that of older animals. Evidently there are individual variations (to be discussed shortly) from this generalized sequence which complicate the data.

An undifferentiated phase during early testicular development is described by Hooker (1944), Sniffen (1952) and Sohval (1958). The tubules in such testes contain a few large gonocytes (germ cells which presumably represent spermatogonia) and many small undifferentiated cells which appear to be the precursors of Sertoli cells and additional genocytes. Undoubtedly the elephant possesses a similar undifferentiated condition during early life. However, a definite division of the seminiferous epithelium into two cell types (spermatogonia and Sertoli cells) seemed apparent in our youngest specimen (No. 60, 1 year of age). The testicular condition in this animal closely resembled the early spermatogonia and Sertoli cells of domestic forms as described by Ortavant (1959). In contrast, the interstitium appears to remain undifferentiated until an approximate age of 2 years. Specimen 74 was the youngest animal in which definite Leydig cells were apparent.

The curves (Text-fig. 1) trace the developmental history of each cell type in seminiferous epithelium relative to testis weight and tubule diameter. Obviously from the scattering of points on these curves, there is considerable variation among individual animals. Nonetheless, the curves appear to approximate logically to the cellular trends during testicular development and in later life. Note the abundance of Sertoli cells and spermatogonia in young tubules with the other seminiferous elements appearing later. A relative constancy in Sertoli cell numbers was noted in the laboratory rat by Roosen-Runge \& Giesel (1950) and in domestic mammals by Ortavant (1959). The elephant displays a similar phenomenon since the position of the Sertoli cell curve corresponds to a constancy of cell numbers as tubular area increases with maturity. The same situation also appears to characterize the spermatogonia.

\section{POTENTIAL VARIABILITY OF THE PUBERTAL PERIOD}

Puberty is a rather ill-defined concept. Hammond \& Marshall (1956) consider puberty to be that time during which the essential organs of reproduction undergo a great increase in size. Asdell (1946) defines puberty as the time at which reproduction first becomes possible (when germ cells are released). More precisely, puberty can be considered as an interval of time whose endpoint coincides with fertility. Such a condition in the male implies the establishment of a certain minimal sperm supply such that fertility is assured. We were unable to assess the testicular condition corresponding to such a level of sperm production in the elephant. Thus, the end of puberty was placed arbitrarily at the time when adult testicular histology was achieved.

Variations in pubertal development are to be expected. A testicular weight of about $700 \mathrm{~g}$ appears to represent the end-point of puberty and the appearance of histologically mature tissue in most individuals (note the break in the curves, Text-fig. 1, at the latter weight level). Specimen 76 is an exception, however, since this animal had attained mature tissue in gonads with a mean weight of only $511 \mathrm{~g}$ (Table 1 ). This latter value may be indicative of the lower 
TABLE 1

A SUMMARY OF TESTICULAR DATA ARRANGED ACCORDING TO APPROXIMATE AGE

\begin{tabular}{|c|c|c|c|c|c|c|c|c|c|}
\hline \multirow[b]{2}{*}{$\begin{array}{l}\text { Speci- } \\
\text { men } \\
\text { No. }\end{array}$} & \multirow[b]{2}{*}{$\begin{array}{c}\text { Approx- } \\
\text { imate } \\
\text { age } \\
(\text { years })\end{array}$} & \multirow[b]{2}{*}{$\begin{array}{c}\text { Testis weight } \\
(\mathrm{g}) \dagger \text { and testis to } \\
\text { body weight }(\mathrm{kg}) \\
\text { ratio } \ddagger\end{array}$} & \multicolumn{7}{|c|}{ Percentage relative abundance* } \\
\hline & & & $\begin{array}{c}\text { Extra- } \\
\text { tubular } \\
\text { area }\end{array}$ & $\begin{array}{l}\text { Intra- } \\
\text { tubular } \\
\text { area }\end{array}$ & $\begin{array}{l}\text { Sperm- } \\
\text { atogonia }\end{array}$ & $\begin{array}{l}\text { Sperm- } \\
\text { atocytes }\end{array}$ & $\begin{array}{l}\text { Sperm- } \\
\text { atid- } \\
\text { sperm- } \\
\text { atozoa }\end{array}$ & $\begin{array}{l}\text { Sertoli } \\
\text { cells }\end{array}$ & Space \\
\hline $\begin{array}{l}60 \\
74 \\
96 \\
55\end{array}$ & $\begin{array}{l}1 \\
2 \\
3 \frac{1}{2} \\
4 \frac{1}{2}\end{array}$ & $\begin{array}{l}13 \cdot 5-0 \cdot 18 \\
18 \cdot 5-0 \cdot 12 \\
23 \cdot 5-0 \cdot 06 \\
30 \cdot 5-0 \cdot 08\end{array}$ & $\begin{array}{l}84 \cdot 7 \\
72 \cdot 9 \\
66 \cdot 4 \\
64 \cdot 0\end{array}$ & $\begin{array}{l}15 \cdot 3 \\
27 \cdot 1 \\
33 \cdot 6 \\
36 \cdot 0\end{array}$ & $\begin{array}{l}14 \cdot 3 \\
31 \cdot 3 \\
20 \cdot 8 \\
14 \cdot 6\end{array}$ & $\begin{array}{l}0 \cdot 0 \\
0 \cdot 0 \\
0 \cdot 0 \\
1 \cdot 4\end{array}$ & $\begin{array}{l}0 \cdot 0 \\
0 \cdot 0 \\
0 \cdot 0 \\
0 \cdot 0\end{array}$ & $\begin{array}{l}61 \cdot 5 \\
50 \cdot 9 \\
40 \cdot 6 \\
53 \cdot 5\end{array}$ & $\begin{array}{l}24 \cdot 2 \\
17 \cdot 8 \\
38 \cdot 7 \\
30 \cdot 5\end{array}$ \\
\hline $\begin{array}{l}94 \\
98 \\
34\end{array}$ & $\begin{array}{l}6 \\
6 \\
6\end{array}$ & $\begin{array}{r}29 \cdot 0-0 \cdot 04 \\
142 \cdot 0-0 \cdot 22 \\
170 \cdot 0-0 \cdot 26\end{array}$ & $\begin{array}{l}48 \cdot 5 \\
37 \cdot 7 \\
52 \cdot 7\end{array}$ & $\begin{array}{l}51 \cdot 5 \\
62 \cdot 3 \\
47 \cdot 3\end{array}$ & $\begin{array}{l}21 \cdot 8 \\
15 \cdot 2 \\
13 \cdot 4\end{array}$ & $\begin{array}{l}4 \cdot 0 \\
3 \cdot 5 \\
9 \cdot 4\end{array}$ & $\begin{array}{l}0.0 \\
0.0 \\
0.0\end{array}$ & $\begin{array}{l}36 \cdot 1 \\
33 \cdot 4 \\
46 \cdot 2\end{array}$ & $\begin{array}{l}38 \cdot 1 \\
47 \cdot 8 \\
31 \cdot 0\end{array}$ \\
\hline $\begin{array}{l}52 \\
95\end{array}$ & $\begin{array}{l}7 \\
7\end{array}$ & $\begin{array}{l}149 \cdot 0-0 \cdot 20 \\
368 \cdot 0-0 \cdot 46\end{array}$ & $\begin{array}{l}47 \cdot 3 \\
38 \cdot 0\end{array}$ & $\begin{array}{l}52 \cdot 7 \\
62 \cdot 0\end{array}$ & $\begin{array}{l}18 \cdot 4 \\
16 \cdot 3\end{array}$ & $\begin{array}{l}3 \cdot 6 \\
6 \cdot 4\end{array}$ & $\begin{array}{l}0.0 \\
1.9\end{array}$ & $\begin{array}{l}31 \cdot 0 \\
31 \cdot 7\end{array}$ & $\begin{array}{l}46 \cdot 8 \\
43 \cdot 6\end{array}$ \\
\hline $\begin{array}{l}61 \\
64\end{array}$ & $\begin{array}{l}8 \\
8\end{array}$ & $\begin{array}{l}361 \cdot 0-0 \cdot 36 \\
312 \cdot 0-0 \cdot 42\end{array}$ & $\begin{array}{l}37 \cdot 5 \\
33 \cdot 0\end{array}$ & $\begin{array}{l}62 \cdot 5 \\
67 \cdot 0\end{array}$ & $\begin{array}{r}14 \cdot 5 \\
9 \cdot 5\end{array}$ & $\begin{array}{l}8 \cdot 1 \\
8 \cdot 2\end{array}$ & $\begin{array}{l}1 \cdot 6 \\
7 \cdot 4\end{array}$ & $\begin{array}{l}27 \cdot 4 \\
30 \cdot 7\end{array}$ & $\begin{array}{l}48 \cdot 4 \\
44 \cdot 0\end{array}$ \\
\hline 87 & 9 & $936 \cdot 0-0 \cdot 76$ & $41 \cdot 2$ & $58 \cdot 8$ & $5 \cdot 5$ & $26 \cdot 7$ & $32 \cdot 5$ & $14 \cdot 4$ & $21 \cdot 0$ \\
\hline 1 & 10 & $1589 \cdot 0-1 \cdot 54$ & $29 \cdot 7$ & $70 \cdot 3$ & $10 \cdot 2$ & $23 \cdot 2$ & $27 \cdot 2$ & $15 \cdot 4$ & $23 \cdot 4$ \\
\hline $\begin{array}{r}8 \\
76\end{array}$ & $\begin{array}{l}11 \\
11\end{array}$ & $\begin{array}{l}794 \cdot 0-0.92 \\
511 \cdot 0-0 \cdot 46\end{array}$ & $\begin{array}{l}34 \cdot 1 \\
33 \cdot 0\end{array}$ & $\begin{array}{l}65 \cdot 9 \\
67 \cdot 0\end{array}$ & $\begin{array}{r}10 \cdot 2 \\
7 \cdot 6\end{array}$ & $\begin{array}{l}32 \cdot 3 \\
26 \cdot 8\end{array}$ & $\begin{array}{l}36 \cdot 9 \\
38 \cdot 3\end{array}$ & $\begin{array}{l}9 \cdot 6 \\
8 \cdot 1\end{array}$ & $\begin{array}{l}10 \cdot 4 \\
19 \cdot 0\end{array}$ \\
\hline $\begin{array}{l}10 \\
19 \\
26\end{array}$ & $\begin{array}{l}12 \\
12 \\
12\end{array}$ & $\begin{array}{r}1021 \cdot 0-0 \cdot 78 \\
964 \cdot 0-0 \cdot 82 \\
716 \cdot 0-0 \cdot 64\end{array}$ & $\begin{array}{l}29 \cdot 1 \\
28 \cdot 4 \\
21 \cdot 2\end{array}$ & $\begin{array}{l}70 \cdot 9 \\
71 \cdot 6 \\
78 \cdot 8\end{array}$ & $\begin{array}{l}7 \cdot 5 \\
8 \cdot 1 \\
6 \cdot 6\end{array}$ & $\begin{array}{l}26 \cdot 6 \\
27 \cdot 5 \\
31 \cdot 7\end{array}$ & $\begin{array}{l}33 \cdot 1 \\
34 \cdot 2 \\
37 \cdot 2\end{array}$ & $\begin{array}{r}7 \cdot 7 \\
10 \cdot 1 \\
8 \cdot 3\end{array}$ & $\begin{array}{l}24 \cdot 9 \\
19 \cdot 8 \\
16 \cdot 2\end{array}$ \\
\hline $\begin{array}{l}35 \\
79 \\
90\end{array}$ & $\begin{array}{l}13 \\
13 \\
13\end{array}$ & $\begin{array}{r}822 \cdot 0-0 \cdot 60 \\
879 \cdot 0-0 \cdot 68 \\
1646 \cdot 0-1 \cdot 06\end{array}$ & $\begin{array}{l}28 \cdot 3 \\
20 \cdot 6 \\
20 \cdot 3\end{array}$ & $\begin{array}{l}71 \cdot 7 \\
79 \cdot 4 \\
79 \cdot 7\end{array}$ & $\begin{array}{l}9 \cdot 5 \\
6 \cdot 5 \\
6 \cdot 3\end{array}$ & $\begin{array}{l}29 \cdot 7 \\
27 \cdot 9 \\
23 \cdot 9\end{array}$ & $\begin{array}{l}22 \cdot 7 \\
34 \cdot 2 \\
33 \cdot 4\end{array}$ & $\begin{array}{r}13 \cdot 0 \\
7 \cdot 8 \\
8 \cdot 2\end{array}$ & $\begin{array}{l}25 \cdot 0 \\
23 \cdot 4 \\
28 \cdot 2\end{array}$ \\
\hline 85 & 14 & $1532 \cdot 0-0 \cdot 94$ & $22 \cdot 5$ & $77 \cdot 5$ & $5 \cdot 8$ & $23 \cdot 8$ & $37 \cdot 1$ & $8 \cdot 1$ & $25 \cdot 2$ \\
\hline 91 & 15 & $1603 \cdot 0-0 \cdot 98$ & $23 \cdot 0$ & $77 \cdot 0$ & $5 \cdot 7$ & $32 \cdot 1$ & $27 \cdot 4$ & $11 \cdot 0$ & 23.7 \\
\hline 78 & 16 & $411 \cdot 0-0 \cdot 32$ & $34 \cdot 9$ & $65 \cdot 1$ & $9 \cdot 1$ & $17 \cdot 9$ & $8 \cdot 0$ & $18 \cdot 2$ & $46 \cdot 9$ \\
\hline $\begin{array}{r}23 \\
89 \\
124\end{array}$ & $\begin{array}{l}17 \\
17 \\
17\end{array}$ & $\begin{array}{l}1397 \cdot 0-0 \cdot 78 \\
1376 \cdot 0-0 \cdot 88 \\
1546 \cdot 0-0 \cdot 76\end{array}$ & $\begin{array}{l}19 \cdot 6 \\
22 \cdot 5 \\
25 \cdot 4\end{array}$ & $\begin{array}{l}80 \cdot 4 \\
77 \cdot 5 \\
74 \cdot 6\end{array}$ & $\begin{array}{l}4 \cdot 2 \\
6 \cdot 1 \\
4 \cdot 6\end{array}$ & $\begin{array}{l}32 \cdot 0 \\
25 \cdot 7 \\
27 \cdot 2\end{array}$ & $\begin{array}{l}34-2 \\
33 \cdot 6 \\
37 \cdot 2\end{array}$ & $\begin{array}{l}5 \cdot 3 \\
8 \cdot 1 \\
8 \cdot 7\end{array}$ & $\begin{array}{l}24 \cdot 1 \\
26 \cdot 6 \\
22 \cdot 1\end{array}$ \\
\hline 42 & 18 & $1220 \cdot 0-0 \cdot 78$ & $18 \cdot 5$ & $81 \cdot 5$ & $5 \cdot 4$ & $28 \cdot 9$ & $35 \cdot 0$ & $9 \cdot 9$ & $22 \cdot 9$ \\
\hline $\begin{array}{r}3 \\
116 \\
86\end{array}$ & $\begin{array}{l}19 \\
19 \\
19\end{array}$ & $\begin{array}{r}1589 \cdot 0-0 \cdot 90 \\
1816 \cdot 0-1 \cdot 16 \\
936 \cdot 0-0-62\end{array}$ & $\begin{array}{l}22 \cdot 9 \\
27 \cdot 2 \\
23 \cdot 4\end{array}$ & $\begin{array}{l}77 \cdot 1 \\
72 \cdot 8 \\
76 \cdot 6\end{array}$ & $\begin{array}{l}6 \cdot 8 \\
4 \cdot 9 \\
6 \cdot 5\end{array}$ & $\begin{array}{l}26 \cdot 8 \\
29 \cdot 6 \\
26 \cdot 3\end{array}$ & $\begin{array}{l}40 \cdot 4 \\
42 \cdot 8 \\
40 \cdot 8\end{array}$ & $\begin{array}{l}2 \cdot 5 \\
7 \cdot 7 \\
9 \cdot 6\end{array}$ & $\begin{array}{l}23 \cdot 5 \\
14 \cdot 7 \\
16 \cdot 6\end{array}$ \\
\hline 119 & 20 & $908 \cdot 0-0 \cdot 48$ & $30 \cdot 6$ & $69 \cdot 4$ & $5 \cdot 6$ & $21 \cdot 7$ & $39 \cdot 9$ & $11 \cdot 5$ & $21 \cdot 0$ \\
\hline 121 & 22 & $695 \cdot 0-0 \cdot 36$ & $28 \cdot 3$ & $71 \cdot 7$ & $4 \cdot 0$ & $32 \cdot 7$ & $37 \cdot 4$ & $8 \cdot 3$ & $17 \cdot 6$ \\
\hline 25 & 25 & $2043 \cdot 0-1 \cdot 02$ & $26 \cdot 9$ & $73 \cdot 1$ & $6 \cdot 7$ & 27.0 & $37 \cdot 2$ & $5 \cdot 1$ & $24 \cdot 0$ \\
\hline 84 & 30 & $2156 \cdot 0-1 \cdot 96$ & $25 \cdot 1$ & $74 \cdot 9$ & $6 \cdot 7$ & $28 \cdot 7$ & $34 \cdot 4$ & $4 \cdot 7$ & $25 \cdot 4$ \\
\hline
\end{tabular}

* Extratubular components (interstitial material plus the sheaths of connective tissue around the tubules) were not considered when calculating the relative abundance of the components of the seminiferous epithelium. All percentage values were obtained through use of the Chalkley technique.

+ Testis weight figures represent the mean weight of both gonads.

$\ddagger$ Ratio calculations $=\frac{\text { Weight of testis }(\mathrm{g})}{\text { Body weight }(\mathrm{kg})}$.

weight level at which histological maturity can be achieved. No. 76 probably began its pubertal development relatively late (Table 1 shows two younger specimens, Nos. 1 and 87, which possessed gonads considerably larger than those of No. 76). 
Considering the gonad weights of Nos. 87 and 1 (9 and 10 years old, respectively), it appears likely that histologically mature testes of relatively low weight (comparable in size to those of No. 76) could be achieved by 7 to 8 years of age. Thus, the latter interval would appear to constitute the lower age limit to mature testicular tissue. Allowing about 4 years for the conversion of the immature testis to a mature histological condition, it seems probable that puberty begins as early as 3 to 4 years of age in some individuals.

With respect to the upper age limit of pubertal development the data are tenuous. However, specimen 78 (16 years of age) probably represents an animal undergoing relatively late pubertal development. There are no other specimens of comparable age (or older) in which the testes are so small; and also the low spermatid-spermatozoa fraction of No. 78 is approached only by younger, definitely pubertal animals (Table 1). Since No. 78 still did not contain completely mature testicular tissue, its pubertal development probably began at about 13 to 14 years of age, and probably would have ended at 17 to 18 years of age.

We can summarize by saying that puberty appears to begin any time from 3 to 14 years of age, with the attainment of maturity occurring from 7 to 18 years of age.

The likelihood of this broad range is strengthened by certain information from the literature. Asdell (1946) mentions that the closeness of fit of several factors (body length, body weight, age, etc.) has been studied relative to puberty in a number of species. From this work the generality has emerged that age is one of the least constant factors in pubertal development. Leathem (1958) points out that mammalian puberty is influenced by an interplay of factors such as genetic differences, time of birth and nutrition. Hooker (1944) shows puberty to occur between 6 months and 1 year in the dairy bull. However, his figures indicate variation in the quantity of spermatozoa being produced by young post-pubertal individuals. Thus, in the concept of puberty as applied to elephant tissues, Hooker's interval could probably be extended. In the human (whose life span is comparable to that of the elephant) there is much variation in male pubertal development. For example, Schonfeld (1943) shows that the pubertal interval generally extends from 11 to 15 years of age, but that puberty may begin as early as 8 years or as late as 18 to 20 years.

There are several records pertaining to elephant puberty which should be mentioned. Flower (1943) states that male Indian elephants (Elephas maximus) complete puberty at 14 to 15 years of age, but notes one instance at 9 years of age. Hindle (1950) describes a fertile mating between two 10-year-old Indian elephants, and Benedict (1936) also advances the latter age for fertility in the Indian elephant. Krumbiegel (1943) considers puberty in the African elephant to take place between 15 and 20 years of age. Buss \& Smith (1966) conclude that some female African elephants begin breeding at about 7 years, that all females are bred by an approximate age of 11 years, and that the average initial breeding age is about 9 years. Perry (1953) feels that most African elephants are fertile by 9 to 10 years of age. All of these observations are probably correct with disagreements merely reflecting individual variation along the potential pubertal span. 
Table 1 reveals considerable variation in testis weights and testis- to body-weight ratios. It seems likely that most of this variability relates either to the pubertal phenomenon or to the normal range of individual variation among mature animals. However, among the older bulls (19 years and above) there are three puzzling individuals (Nos. 86, 119 and 121) which contained testes of considerably less weight than comparable specimens. This relationship may reflect a cyclic phenomenon which will be considered in a later publication. Alternatively, these three specimens represent late-puberty animals.

Maximal testicular weight values for mature elephants apparently are greater than those revealed by the collection series. The largest testes obtained weighed (mean of both organs) $2043 \mathrm{~g}$ (specimen 25) and $2156 \mathrm{~g}$ (specimen 84),

TABLE 2

A COMPARISON OF THE TESTIS TO BODY WEIGHT

RATIO IN VARIOUS MAMMALS

\begin{tabular}{l|c}
\hline \multicolumn{1}{c|}{ Species* } & $\begin{array}{c}\text { Ratio of testis weight }(\mathrm{g}) \\
\text { to body weight }(\mathrm{kg}) \dagger\end{array}$ \\
\hline Hamster & $34 \cdot 80$ \\
Rat & 8.90 \\
Mouse & 7.50 \\
Monkey (Macaca irus) & $6 \cdot 76$ \\
Chimpanzee & $2 \cdot 70$ \\
Dog & 1.90 \\
Domestic bull & $1 \cdot 24$ \\
Elephant (present study) & $1.00^{\ddagger}$ \\
Gibbon and man & 0.80 \\
Orang-utan & 0.50 \\
\hline
\end{tabular}

* Primate data from Schultz (1938); Domestic bull data from Abdel-Raouf (1960); other data (except for elephant) from Leathem \& Wolf (1955).

$\dagger$ Ratio calculations $=\frac{\text { Weight of testes }(\mathrm{g})}{\text { Body weight }(\mathrm{kg})}$.

$\ddagger$ Ratio represents a mean obtained from seven relatively mature specimens (see Part I of this paper).

respectively (Table 1). Perry (1953) mentions testis weights ranging from 2 to $3 \mathrm{~kg}$ in Uganda elephants. The greatest deviation from the present study was reported by Quiring (1939) who dissected a specimen killed somewhere in East Africa (exact location not specified). The mean weight for the testes of this animal was $4396 \mathrm{~g}$. Benedict \& Lee (1938) cite correspondence with the members of Quiring's expedition which attests to the accuracy of the scales used. Information on the weight of Indian elephant testes agrees well with the testicular weights represented in our collection. Noback (1932) autopsied a 28-year-old animal which had testes weighing 1.6 and $1.8 \mathrm{~kg}$, respectively; and Schulte (1937) gives the testis weights of a 20 -year-old specimen as 1.8 and 2.2 $\mathrm{kg}$, respectively.

In terms of relative weight, the African elephant testis is not impressively large. Testis- to body-weight ratios for a variety of mammals are shown in Table 2. 
Although the elephant testis is small in relative terms, its tubular and cellular dimensions are comparable to those of the human testis as given by Tillinger (1957) and Sohval (1958). Hence a much larger quantity of spermatogenic epithelium can be accommodated within the elephant testis as compared to the human testis. Thus the elephant testis, though small in comparative terms, has the potential to produce vast numbers of spermatozoa provided that its meiotic rate is similar to that of the human and other mammals.

\section{ACKNOWLEDGMENTS}

Field work (by the junior author) was supported by a Senior Fulbright Research Scholarship, a National Science Foundation grant, a grant from the New York Zoological Society, and by funds from the Forest Department of Uganda. Laboratory work was supported through the State of Washington's Initiative Measure No. 171. Dr R. A. Parker assisted with certain statistical aspects of this work and constructively criticized the manuscript. Dr G. W. McNeil and Miss Leola Lorenzen gave valuable assistance with certain photographic techniques. Dr H. L. Eastlick, Dr M. T. James, Dr R. F. Daubenmire and Dr M. H. Bartel constructively read the manuscript.

\section{REFERENCES}

ABdel-Raouf, M. (1960) The postnatal development of the reproductive organs in bulls with special reference to puberty. Acta endocr., Copenh. Suppl. 49.

Asdeli, S. A. (1946) Patterns of mammalian reproduction. Comstock Publishing Co., Ithaca, New York. BENEDICT, F. G. (1936) The physiology of the elephant. Carnegie Institute, Washington.

Benedict, F. G. \& LeE, R. C. (1938) Further observations on the physiology of the elephant. $\mathcal{F}$. Mammal. 19, 175.

Buss, I. O. \& Sмгтн, N. S. (1966) Observations on reproduction and breeding behavior of the African elephant. F. Wildl. Mgmt, 30, 375.

FLower, S. S. (1943) Notes on age at sexual maturity, gestation period, and growth of the Indian elephant (Elephas maximus). Proc. zool. Soc. Lond. 113, 21.

Hammond, J. \& Marshald, F. H. A. (1956) The life cycle. Marshall's Physiology of Reproduction, vol. 2, chap. 23. Ed. A. S. Parkes. Longmans Green, London.

Hindle, E. M. (1950) Birth of an elephant in the Rome zoo. Zoo Life, 5, 7.

HOOKER, C. W. (1944) The postnatal history and function of the interstitial cells of the testis of the bull. Am. 7. Anat. 74, 1.

Johnson, O. W. \& Buss, I. O. (1967) The testis of the African elephant (Loxodonta africana). I. Histological features. $\mathcal{F}$. Reprod. Fert. 13, 11.

Krumbiegel, I. (1943) Der Afrikanische Elefant. Monographien der Wildsäugetiere, Band 9.

LEATHEM, J. H. (1958) The effects of aging on reproduction. In: The Endocrinology of Reproduction, chap. 9. Ed. J. T. Velardo. Oxford University Press, New York.

Leathem, J. H. \& Wolf, R. G. (1955) The varying effects of sex hormones in mammals. The Comparative Physiology of Reproduction, p. 220. Eds. I. G. Jones and P. Eckstein. Mem. Soc. Endocr. No. 4. Cambridge University Press.

Noваск, C. V. (1931) Report of the veterinarian. New York Zoological Society, 36th Annual Report, p. 58.

Ortavant, R. (1959) Spermatogenesis and morphology of the spermatozoan. Reproduction in Domestic Animals, vol. 2, chap. 1. Ed. H. H. Cole and P. T. Cupps. Academic Press, New York.

Perry, J. S. (1953) The reproduction of the African elephant (Loxodonta africana). Phil. Trans. R. Soc. B, 237, 93.

Quiring, D. P. (1939) Notes on an African elephant. Growth, 3, 9.

Roosen-Runge, E. G. \& Giesel, L. O. (1950) Quantitative studies on spermatogenesis in the albino rat. Am. 7. Anat. 87, 1.

Schonfeld, W. A. (1943) Primary and secondary sexual characteristics; a study of their development in males through maturity, with biometric study of penis and testes. Am. F. Dis. Child. 65, 535. 
Schulte, T. L. (1937) The genito-urinary system of the Elephas indicus male. Am. F. Anat. 61, 131.

Schultz, A. H. (1938) The relative weight of the testes in primates. Anat. Rec. 72, 387.

SNIfFEN, R. G. (1952) Histology of the normal and abnormal testis at puberty. Ann. N.r. Acad. Sci. $55,609$.

Sohval, A. R. (1958) The anatomy and endocrine physiology of the male reproductive system. In: The Endocrinology of Reproduction, chap. 8. Ed. J. T. Velardo. Oxford University Press, New York.

Tillinger, K. G. (1957) Testicular morphology. Acta endocr., Copenh. Suppl. 30. 